\section{FORDULAT A HALANDÓSÁGBAN?}

Horváth Gyula (Aegon Magyarország - pénzügyi vezérigazgató-helyettes, az IAA Mortality Working Group tagia)

\section{ÖSSZEFOGLALÓ}

A nemzetközi aktuáriusi és demográfusi szakmát az elmúlt években erősen foglalkoztatja a halandóság javulásának lassulása. Az Egyesült Államok férfi népessége körében egyenesen romlást látunk. A jelenség kevés kivételtől eltekintve a fejlett világ egészét jellemzi, ugyanakkor a megfigyelési időszak meglehetősen rövid ahhoz, hogy határozott véleményt formáljunk. Mégis érdekes lehet elkezdeni a lehetséges okok vizsgálatát. Jelen cikk elsősorban a Nemzetközi Aktuárius Társaság Halandósági Munkacsoportjában, illetve a berlini aktuárius világkongresszuson elhangzott előadásokra, illetve némi saját számításra támaszkodik.

\section{SUMMARY}

There is an ongoing interest in the international actuarial and demographic profession around the slowing down of the improvement of mortality. In case of the US male population the mortality is even getting worst. The phenomenon exists throughout the developed world, with only few exceptions, although the observation period is too short to form a firm opinion. However, it may be interesting to begin examining some possible causes. This article is based on the presentations made in the Mortality Working Group of the International Actuarial Society and during the International Congress of Actuaries (Berlin) and some own calculations.

Kulcsszavak: demográfiai trendek, halandóság, várható élettartam Keywords: demographic trends, mortality, life expectancy

\section{JEL: J11}

DOI: $10.18530 / \mathrm{BK} .2019 .3 .18$

http://dx.doi.org/10.18530/BK.2019.3.18

\section{Bevezetés}

A halandósággal foglalkozó nemzetközi aktuáriusi körökben mind fontosabb téma a halandóság javulásának lassulása, helyenként leállása. Vajon egy látszólagos jelenséggel állunk szemben, ami belefér a véletlen folyamatokat jellemző ingadozásokba, esetleg az elmúlt évek egyszeri eseményei adják a magyarázatot, vagy valóban trendforduló zajlik? Mivel viszonylag rövid időszak megfigyeléseiből kell kiindulnunk, az idősorelemzés eszköztára nem alkalmazható.

Jelen cikk három célt tűzött maga elé. Bemutatni néhány tényt és az ezzel kapcsolatos nemzetközi elemzéseket, illetve néhány kiválasztott ország példáján keresztül hozzájárulni a jelenség mélyebb elemzéséhez.

A nemzetközi kitekintés az International Actuarial Association (IAA) keretében elhangzó előadásokra koncentrál, így az International Congress of Actuaries (ICA - Berlin, 2018), illetve az IAA Mortality Working Group (MWG) félévenkénti ülésein ismertetett anyagokra.

Fontos hangsúlyozni, hogy a jelenséget csak a fejlett világban detektálták és elemezték (ún. nyugati kultúrkör és Japán), ezért ez a cikk is erre a területre koncentrál.

\section{A mortalitás fejlődése a II. világháború után}

A második világháború után a halandóság az egész világon látványosan javult. Míg az 1950-1955 közötti időszakban a születéskor várható élettartam 47 év volt, ez a 2015-2020-as időszakra 25,3 évvel 72,3 évre nőtt. A fejlődés mindkét nem esetében hasonló, a nőknél 26,2 év $(48,5 \rightarrow 74,7)$ a férfiaknál $24,5(45,5 \rightarrow 70)$, ami természetesen azt is jelenti, hogy a nemek közötti különbség tovább nőtt. ${ }^{1}$

Ez a fejlődés sok okra vezethető vissza, orvosi technikák, higiénés viszonyok fejlődése stb., de ennek tárgyalása nem része a témánknak.

A fejlődés - ahogy ezt a melléklet 1. és 2. táblájában láthatjuk - összességében minden régióra igaz, bár jelentősen különböző mértékben. Ami érdekes (és valószínűleg ritka az emberiség járványokkal és háborúkkal tarkított történetében), hogy az egyes 5 éves időszakokat összehasonlítva szinte minden esetben fejlődést tapasztalunk. Ez alól csak néhány kivétel van.

1990-95 között a Szaharától délre fekvő Afrikában mind a nők, mind a férfiak esetében csökkenést látunk, ami részben a polgárháborúk (Ruanda, Burundi, Sierra Leone), részben az Afrika déli részén végigsöprő HIV járvány következménye volt. ${ }^{2}$ A másik negatív teljesítményű régió Kelet-Európa a rendszerváltás előtt a férfiaknál 1970-1985 között. A jelenség a magyar olvasók számára sem ismeretlen, általában „demográfiai katasztrófa” néven szoktunk hivatkozni rá. Az 1985-2000-es időszakban ugyan regionálisan javult a helyzet, de ez szinte csak a Szovjetunió szláv köztársaságainak köszönhető, valószínűleg a сухой закон, a száraz-törvény hatása. ${ }^{3}$ A rendszerváltás után ismét negatív a régió teljesítménye, a férfiaknál 2005-ig, a nőknél 2000-ig. Ez azonban két ellenkező hatás eredője, a Szovjetunión kívüli kelet-európai országok elkezdtek kilábalni a demográfiai 
válságból, a volt Szovjetunió viszont még mélyebbre süllyedt. Mindennek következményeképpen sem a nők, sem a férfiak esetében nem sikerült lényegében csökkenteni Kelet-Európa örökölt hátrányát.

Még két helyen látunk a férfiaknál regionális csökkenést: egy kismértékűt a hatvanas évek második felében Ausztráliában, illetve a 2010-es évek második felében az Egyesült Államokban. Az utóbbi azért is keltett feltünést, mert a fejlett világban ilyenfajta viszszaesésre (még ha csak csekély mértékben is) nincs példa az 1960-as évek óta.

\section{A javulás ütemének lassulása 2000 után}

Bár az előző fejezet végén említett USA-adat árnyalja az általánosan pozitív képet, a fejlődés egyébként folyamatos. A kutatók ebből időnként radikális, időnként „csak” a trendeket kivetítő következtetéseket vontak le. Például 2015-ben egy csapat arra a következtetésre jutott, hogy mivel 1981 és 2012 között Angliában és Walesben a születéskor várható élettartam 8,2 évet nőtt a férfiakra és 6 évet a nőkre (0,26, illetve 0,19 év évente), 2030 -ig a növekedés 0,34 , illetve 0,24 év/év ütemre gyorsul. ${ }^{4}$ Mások már a kvázi-örök életről írnak, pl. Ray Kurzweil a SENS alapítványtól Fantastic Voyage című könyvében. Szerinte már megszületett az az ember, aki 1000 évig fog élni.

Az utóbbi években viszont a fejlődés lassulása keltette fel a kutatók érdeklődését. $\mathrm{Az}$ 1. táblázat 10 éves lépésközönként mutatja az $\mathrm{e}_{0}$ (születéskor várható élettartam) változását. Ahol ez a lassulás megfigyelhető, az részben éppen a fejlett világ (Európa Kelet-Európa nélkül, Észak-Amerika és a nagyobb csendes-óceáni államok). Hasonló jelenséget mutatnak más térségek is, de ezekkel részben terjedelmi okokból, nagyobb részben ismerethiány miatt nem foglalkozunk.

1. táblázat: Születéskor várható élettartam növekedése 10 éves összehasonlításban

\begin{tabular}{|l|c|c|c|c|c|c|}
\hline & \multicolumn{3}{|c|}{ Férfiak } & \multicolumn{3}{c|}{ Nök } \\
\hline Régió & $\begin{array}{c}(2005-2010)- \\
(1995-2000)(1)\end{array}$ & $\begin{array}{c}(2015-2020)- \\
(2005-2010)(2)\end{array}$ & $(2) /(1)$ & $\begin{array}{c}(2005-2010)- \\
(1995-2000)(3)\end{array}$ & $\begin{array}{c}(2015-2020)- \\
(2005-2010)(4)\end{array}$ & $(4) /(3)$ \\
\hline Világ & 3,4 & 3,3 & $97 \%$ & 3,2 & 3,5 & $109 \%$ \\
\hline Afrika (Szaharától délre) & 4,9 & 6,2 & $127 \%$ & 4,4 & 6,8 & $154 \%$ \\
\hline Észak-Afrika és Nyugat-Ázsia & 3,3 & 2,5 & $75 \%$ & 3,2 & 2,2 & $71 \%$ \\
\hline Közép- és Dél-Ázsia & 3,8 & 3,3 & $88 \%$ & 4,1 & 3,8 & $92 \%$ \\
\hline Kelet-és Délkelet-Ázsia & 3,1 & 2,6 & $84 \%$ & 3,0 & 3,1 & $103 \%$ \\
\hline Latin-Amerika és a karibi térség & 2,7 & 1,8 & $67 \%$ & 2,8 & 1,7 & $62 \%$ \\
\hline Ausztrália és Új-Zéland & 3,2 & 2,0 & $63 \%$ & 2,1 & 1,5 & $69 \%$ \\
\hline Ócé́nia & 2,4 & 2,6 & $107 \%$ & 2,3 & 2,6 & $110 \%$ \\
\hline Európa és Észak-Amerika & 2,4 & 2,8 & $118 \%$ & 1,8 & 1,9 & $105 \%$ \\
\hline Kelet-Európa & 1,6 & 4,8 & $300 \%$ & 1,7 & 3,3 & $194 \%$ \\
\hline
\end{tabular}

\begin{tabular}{|l|l|l|l|l|l|l|}
\hline Észak-Európa & 2,9 & 2,3 & $79 \%$ & 2,1 & 1,5 & $70 \%$ \\
\hline Dél-Európa & 2,9 & 2,4 & $84 \%$ & 2,2 & 1,6 & $75 \%$ \\
\hline Nyugat-Európa & 2,9 & 1,9 & $64 \%$ & 2,0 & 1,2 & $60 \%$ \\
\hline Észak-Amerika & 2,2 & 0,8 & $35 \%$ & 1,4 & 0,7 & $54 \%$ \\
\hline
\end{tabular}

Forrás: UN: World Population Prospects, saját számitás (2019)

Természetesen nemcsak régiókra, hanem országokra lebontva is vizsgálták a lassulást, amit a 2. táblázat mutat.

2. táblázat: A születéskor várható élettartam éves növekedése

\begin{tabular}{|c|c|c|c|c|c|c|c|}
\hline \multirow[t]{2}{*}{ Ország } & \multirow[t]{2}{*}{ Utolsó év } & \multicolumn{2}{|l|}{ Férfi } & \multicolumn{2}{|l|}{ Nö } & \multicolumn{2}{|c|}{$\begin{array}{l}\text { Csökkenés } \\
\text { az éves növekedésben }\end{array}$} \\
\hline & & Elözö 5 év & Utolsó 5 év & Elözö 5 év & Utolsó 5 év & Férfi & Nö \\
\hline Franciaország & 2016 & 0,240 & 0,200 & 0,160 & 0,080 & 0,040 & 0,080 \\
\hline Németország & $2013 / 14$ & 0,260 & 0,134 & 0,162 & 0,094 & 0,126 & 0,068 \\
\hline Olaszország & 2015 & 0,239 & 0,172 & 0,153 & 0,061 & 0,067 & 0,092 \\
\hline Hollandia & 2015 & 0,320 & 0,180 & 0,220 & 0,080 & 0,140 & 0,140 \\
\hline Spanyolország & 2015 & 0,406 & 0,175 & 0,299 & 0,076 & 0,231 & 0,223 \\
\hline Svédország & 2016 & 0,218 & 0,154 & 0,152 & 0,084 & 0,064 & 0,068 \\
\hline Egyesültt Királyság & 2015 & 0,304 & 0,132 & 0,230 & 0,072 & 0,172 & 0,158 \\
\hline Magovarorszáo & 2015 & 0.400 & 0.320 & 0.280 & 0.080 & 0.040 & 0.200 \\
\hline
\end{tabular}

Forrás: Ridsdale, Brian: Is mortality still improving? ${ }^{5}$

\section{A halandóság korcsoportos változása}

A születéskor várható élettartam ugyan hasznos indikátora a halandóság vizsgálatának, de legalább három szempontból nem tudjuk vele kielégítő módon elemezni tárgyunkat:

1. Keresztmetszeti jellegéből fakadóan nem mutathatja meg, hogy egy adott évben született korosztály valóságosan milyen halandósági pályát fut majd be.

2. Változása mögött az okspecifikus halandóság változása áll, ezért előrejelzése csak idősorelemzési eszközökkel nagyon nehéz, hiszen a különböző halálokok jövendő fejlődését és azok egymás közötti összefüggését is elemeznünk kellene. Példaként: a kardiovaszkuláris halandóság csökkenése magával hoz(hat)ja más halálokok növekedését, összességében mégis pozitív hatású a halandóságra.

3. A születéskor várható élettartam változásában a különböző korcsoportok halandóságának változása van „elrejtve”, ami előrejelzési/elemzési szempontból szintén 
fontos. Ez utóbbit kívánják előrejelzési szempontból kezelni az olyan módszerek, mint például a Lee-Carter modell.

A következőkben öt ország korcsoportos halandóságát vizsgálom az 1997-2017-es időszakban. A cél a lassulás jelenségét korcsoportosan is elemezni. Az országokat úgy választottam ki, hogy négyen a fejlett világot reprezentálják földrajzilag diverzifikált módon (Egyesült Államok (USA), Japán (JAP), Németország (GER), Ausztria (AUS)). Az ötödik ország Magyarország (HU).

A népességet 5 korcsoportba osztottam: csecsemők (0 évesek), fiatalok (1-18), fiatal felnőttek (19-40), idősebb felnőttek (41-65) és idősek (65+).

Az alkalmazott módszertan a korfüggő halandósági valószínűségek lépésenkénti cseréjén alapszik. Példaként: ha azt akarjuk mérni, hogy 1997 és 2007 között a csecsemőhalandóság változása hogyan hatott a születéskor várható élettartam növekedésére, akkor az 1997-es táblában a 0 éves kori halandóságot kicseréljük a 2007-es adatra, és így újra számoljuk a várható élettartamot. A következő lépésben kicseréljük az 1-18 éves halandóságot, stb. Képletekkel:

Legyen

$q_{x, t}$ az $x$ éves kori halálozási valószínűség a $t$, évi halandósági tábla szerint $l_{0}=1$ a halandósági tábla nyitó értéke

$l_{x}=l_{x-1}\left(1-q_{x}\right)(x=1, \ldots, \omega)$ a halandósági tábla további elemei, ahol $q_{x}$ a megfelelö halandósági táblából származik

$t_{0}$ és $t_{1}$ a vizsgált időszak eleje és vége

$\omega$ az emberi életkor végső határa.

Ekkor

(1) $e_{0, t_{0}}=\sum_{0}{ }^{\omega} l_{i, t_{0}}-0,5$ a $t_{0}$ évi halandósági tábla szerinti születéskor várható élettartam.

Hasonlóképpen

(2) $e_{0, t_{1}}=\sum_{0}{ }^{\omega} l_{i, t_{1}}-0,5$ a $t_{1}$ évi tábla szerinti születéskor várható élettartam.

Célunk a

(3) $\Delta e_{0}=e_{0, t_{1}}-e_{0, t_{0}}$ különbség elemzése.

Amennyiben azt kívánjuk meghatározni, hogy a $k$, életév és az $r$, életév közötti halandósági változás mennyiben járult hozzá $\Delta e_{0}$-hoz, akkor előállítunk két halandósági táblát. Az elsőben az első $k$ év $q_{x+0}$ értékeit cseréljük le $q_{x+1}$-re és így számolunk (1) szerint születéskor várható élettartamot, majd a cserét $r$ évre hajtjuk végre. A két születéskor várható élettartam különbsége adja az adott korévek hozzájárulását a változáshoz.
Az adatok a Human Mortality Database-ből ${ }^{6}$ származnak, a főbb eredményeket nemenként a 3. és 4. táblázat tartalmazza.

3. táblázat: Hozzájárulás a születéskor várható élettartam változásához korcsoportonként, férfiak

\begin{tabular}{|l|c|c|c|c|c|c|c|c|c|c|}
\hline & \multicolumn{2}{|c|}{ Magyarország } & \multicolumn{2}{|c|}{ Ausztria } & \multicolumn{2}{|c|}{ Németország } & \multicolumn{2}{|c|}{ Egyesült Államok } & \multicolumn{2}{|c|}{ Japán } \\
\cline { 2 - 13 } & $1997-2007$ & $2007-2017$ & $1997-2007$ & $2007-2017$ & $1997-2007$ & $2007-2017$ & $1997-2007$ & $2007-2017$ & $1997-2007$ & $2007-2017$ \\
\hline Csecsemő & $0,3-$ & 0,2 & 0,0 & 0,1 & 0,1 & 0,1 & 0,0 & 0,1 & 0,1 & 0,1 \\
\hline Fiatalkorú & 0,1 & 0,1 & 0,1 & 0,0 & 0,1 & 0,1 & 0,1 & 0,0 & 0,1 & 0,0 \\
\hline $\begin{array}{l}\text { Fiatal } \\
\text { felnött }\end{array}$ & 0,6 & 0,4 & 0,4 & 0,3 & 0,4 & 0,2 & 0,1 & 0,5 & 0,1 & 0,2 \\
\hline $\begin{array}{l}\text { Idősebb } \\
\text { felnött }\end{array}$ & 1,0 & 2,0 & 1,0 & 0,7 & 0,9 & 0,6 & 0,5 & $-0,6$ & 0,5 & 0,7 \\
\hline Idős & 0,6 & 0,7 & 1,8 & 0,8 & 1,5 & 0,8 & 1,3 & 0,7 & 1,2 & 1,0 \\
\hline Összesen & 2,6 & 3,3 & 3,3 & 2,0 & 3,0 & 1,6 & 2,0 & 0,8 & 1,9 & 2,0 \\
\hline
\end{tabular}

Forrás: $H M D$, saját számítás

4. táblázat: Hozzájárulás a születéskor várható élettartam változásához korcsoportonként, nők

\begin{tabular}{|l|c|c|c|c|c|c|c|c|c|c|}
\hline & \multicolumn{2}{|c|}{ Magyarország } & \multicolumn{2}{|c|}{ Ausztria } & \multicolumn{2}{|c|}{ Németország } & \multicolumn{2}{|c|}{ Egyesült Államok } & \multicolumn{2}{|c|}{ Japán } \\
\cline { 2 - 12 } & $1997-2007$ & $2007-2017$ & $1997-2007$ & $2007-2017$ & $1997-2007$ & $2007-2017$ & $1997-2007$ & $2007-2017$ & $1997-2007$ & $2007-2017$ \\
\hline Csecsemő & 0,2 & 0,2 & 0,1 & 0,0 & 0,1 & 0,0 & 0,0 & 0,1 & 0,1 & 0,1 \\
\hline Fiatalkorún & 0,0 & 0,0 & 0,1 & 0,0 & 0,1 & 0,0 & 0,1 & 0,0 & 0,1 & 0,0 \\
\hline $\begin{array}{l}\text { Fiatal } \\
\text { felnött }\end{array}$ & 0,3 & 0,1 & 0,1 & 0,0 & 0,2 & 0,0 & 0,0 & $-0,1$ & 0,0 & 0,1 \\
\hline $\begin{array}{l}\text { Idősebb } \\
\text { felnött }\end{array}$ & 0,5 & 0,7 & 0,4 & 0,3 & 0,4 & 0,2 & 0,3 & 0,1 & 0,3 & 0,3 \\
\hline Idős & 1,1 & 0,6 & 1,6 & 0,6 & 1,4 & 0,6 & 0,8 & 0,7 & 1,7 & 0,9 \\
\hline Összesen & 2,1 & 1,7 & 2,3 & 1,1 & 2,1 & 0,9 & 1,2 & 0,8 & 2,2 & 1,4 \\
\hline
\end{tabular}

Forrás: HMD, saját számitás

A magyar és a japán férfiak adatain kívül minden vizsgált esetben megfigyelhetjük a lassulás jelenségét.

Mint látható, a csecsemőhalandóság élettartam-növelő hatása már csak az e tekintetben az időszak kezdetén a többi négy országtól elmaradt Magyarország esetében volt számottevő. A 5. táblázat igazolja is ezt, egyben sikeres felzárkózást is mutat. A japán adat azonban azt mutatja, hogy van hova fejlődni. Hosszú távon már nem várhatjuk, hogy a csecsemőhalandóság csökkenése lényegesen javítsa az élettartamot. 
Csak összehasonlításképpen: 1950-1960 között a magyar férfiak esetében ez a hozzájárulás még 2,7 év volt.

\section{5. táblázat: Csecsemőhalandóság alakulása}

\begin{tabular}{|l|r|r|r|r|r|r|r|r|r|r|}
\hline & \multicolumn{2}{|c|}{ Magyarország } & \multicolumn{2}{|c|}{ Ausztria } & \multicolumn{2}{|c|}{ Németország } & \multicolumn{2}{|c|}{ Egyesült Államok } & \multicolumn{3}{|c|}{ Japán } \\
\cline { 2 - 11 } & $1997-2007$ & $2007-2017$ & $1997-2007$ & $2007-2017$ & $1997-2007$ & $2007-2017$ & $1997-2007$ & $2007-2017$ & $1997-2007$ & $2007-2017$ \\
\hline Férfiak & $1,07 \%$ & $0,39 \%$ & $0,45 \%$ & $0,30 \%$ & $0,54 \%$ & $0,35 \%$ & $0,82 \%$ & $0,62 \%$ & $0,39 \%$ & $0,19 \%$ \\
\hline Nók & $0,84 \%$ & $0,31 \%$ & $0,46 \%$ & $0,28 \%$ & $0,43 \%$ & $0,30 \%$ & $0,67 \%$ & $0,51 \%$ & $0,34 \%$ & $0,18 \%$ \\
\hline
\end{tabular}

Forrás: $H M D$

A fiatalkorú halandóság javulása már sehol sem mutat lényeges potenciált. A vizsgált öt országban a férfiak esetében 20 év alatt 0,14-0,16 évvel járult hozzá a születéskor várható élettartam javulásához, a nőknél ez az adat 0,08-0,1 év. Érdekes, hogy e tekintetben nincs lényeges különbség az országok között. Ez az adat 1950-1960 között még 1 év volt a magyar fiúk esetében. Mindez érthető, hiszen e korosztályban nagyon közel kerültünk a 100\%-os túlélési valószínűséghez (99,6\%-99,8\% nemtől és országtól függően)

A magyar idősebb felnőttek esetében a demográfiai katasztrófából való kilábalás miatt még tart a gyorsuló javulás.

A fiatal felnőttek (18-40 évesek) esetében az Egyesült Államokban fordulat történt, az elmúlt évtizedben mindkét nem esetében romlott a halandóság. Ennek eredményeképpen az amerikai adat messze rosszabb, mint a többi országé: férfiaknál a halálozási valószínűség 3,8\% (a többieknél 1,9-1,3\%), a nőknél 1,7\% (a többi esetben 0,9-0,6\%). Érdemes megjegyezni, hogy bár a magyar adat a legrosszabb a négy ország közül, de nem áll tőlük távol.

$\mathrm{Az}$ idősebb felnőttek esetében a kép nem ilyen egyértelmű. A halandósági viszonyok mindenütt javultak, kivéve az amerikai férfiakat. A magyar idősebb felnőttek esetében a demográfiai katasztrófából való kilábalás miatt még tart a gyorsuló javulás, a többi három országot a lassuló javulás jellemzi. Maguk a halálozási valószínűségek is rendkívül szórtak. Míg egy magyar férfi esetében $25,1 \%$ százalék a valószínűsége annak, hogy meghal ezekben a korévekben, egy átlagos japán esetében ez csak 9,9\%. Nőknél ugyanezek a számok $12,1 \%$ és $4,6 \%$.

Az idősek (65+) körében a halandóság javulásának lassulása a magyar férfiak kivételével mindenütt megfigyelhető. Ugyanakkor a magyar helyzet messze a legrosszabb a vizsgált országok között: a 65 éves korban várható élettartam nálunk a férfiakra 14,4 év, a nőkre 18,3 2017-ben, míg a többieknél 17,9-19,6 a férfiakra és 20,9-24,5 a nőkre. „Természetesen” mindenütt a japán adat a legmagasabb.

\section{Magyarázatok}

Mint már említettem, a magyarázatok forrásai nagyrészt az IAA keretében elhangzott előadások vagy az ott hivatkozott elemzések. Ezeket néhány főbb csoportba soroltam, és ezek mentén mutatom be.

Az első csoport a jelenség átmeneti voltát sugallja, és a jelenséget a véletlen ingadozás kategóriájába sorolja: volt néhány rossz évünk, de ez még nem jelent komoly változást.

A második azt mutatja be, hogy a halandóságot befolyásoló egyes tényezők körében sikerült ugyan elörelépnünk (pl. dohányzás), de más területeken rosszabbodott a helyzet.

A harmadik magyarázat a jelenséget - a másodikhoz hasonlóan - nem láttatja átmenetinek, és a magyarázatot a nyugati társadalmak változásában látja. Fontos megjegyezni, hogy a második és a harmadik magyarázat között lehet/van összefüggés: a kilátástalanság, a szegénység önpusztító magatartásokat szülhet.

Végül van olyan álláspont is, hogy kimerülőben vannak a további javulás lehetőségei, ezért ez természetes folyamat.

\section{A jelenség pusztán átmeneti, mivel „pechünk van/volt”}

E magyarázatok egyrészt a véletlen ingadozást említik, és azt, hogy a jelenség túl rövid távú ahhoz, hogy statisztikailag elemezhető legyen. Ez az érvelés szinte minden előadásban megjelent mint lehetséges magyarázat.

A „pechünk volt” érvelést használók hivatkozhatnak az EuroMOMO adataira. Az EuroMOMO 24 európai ország heti mortalitási adatait mutatja be. Az 1. ábrán korcsoportos bontásban és összességében mutatják be az adatokat, összehasonlítva őket a szokásos ingadozással. Mint láthatjuk 2015, 2017, 2018 és 2019 esetében is a téli-kora tavaszi halandóság lényegesen meghaladta a szokásost. Ez a szokásos szintet meghaladó halandóság nem érintette a gyerekeket, kismértékben sújtotta a felnőtteket, viszont súlyos hatása volt az idősek esetében.

Amennyiben ezt a(z influenza) járványok rovására írjuk, akkor már csak az a kérdés marad nyitva, hogy ideiglenes-e a jelenség, vagy olyan új járványokkal találkozunk, amelyek ellen még nem tudunk védekezni. Véleményem szerint, ha öt évből négy mutat hasonló tendenciát, akkor ezt nem intézhetjük el balszerencsére hivatkozva. 


\section{1. ábra: Heti haladósági adatok alakulása 28 európai országban}

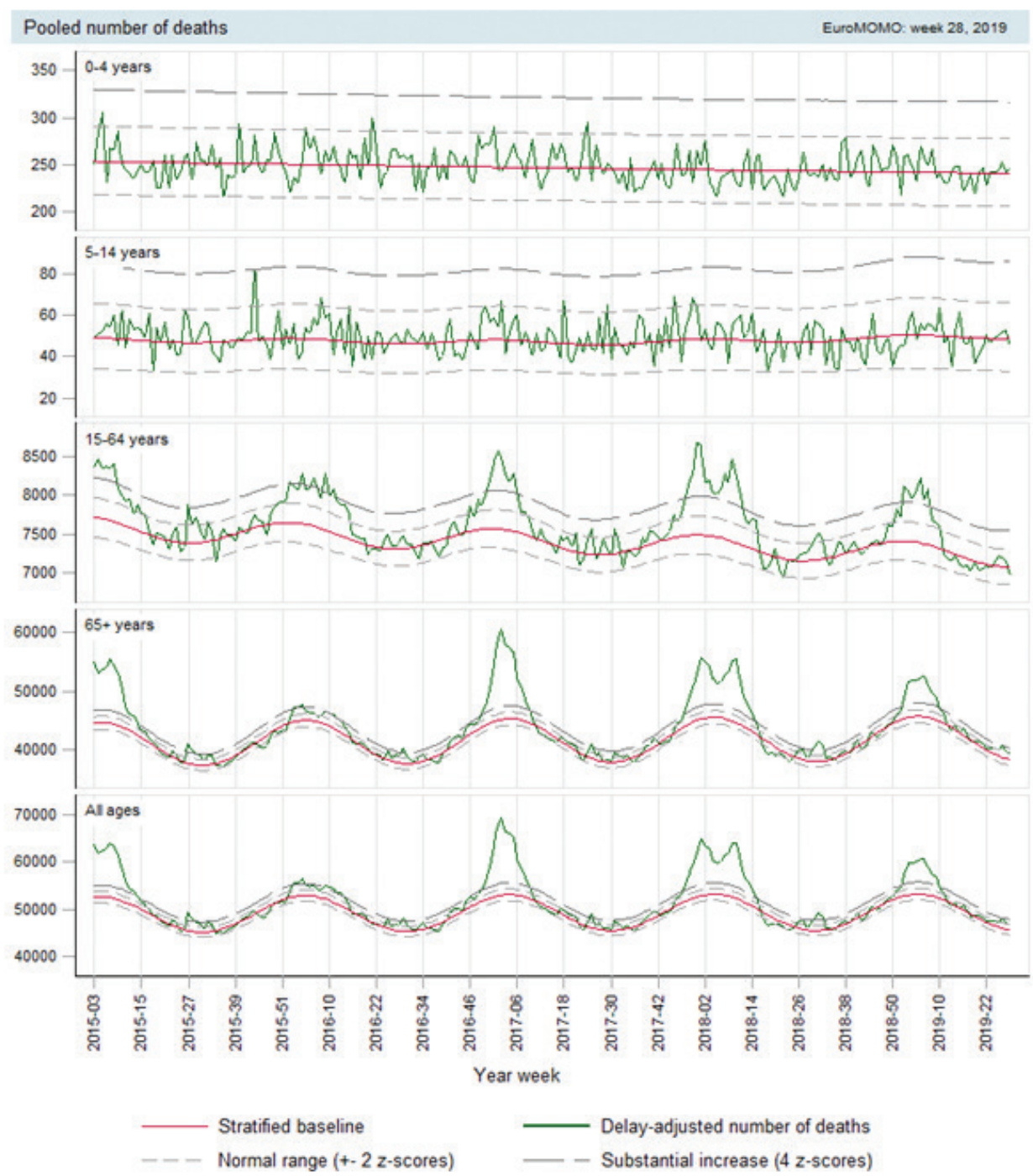

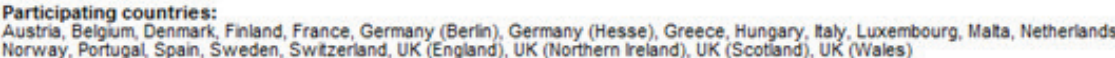

Forrás: EuroMOMO

\section{Az önpusztítás új módjai}

A halandóság alakulására nemcsak az általános egészségügyi és higiéniás viszonyok vannak hatással, hanem az egyéni viselkedés is. Az elmúlt évtizedekben elsőként a dohányzás visszaszorítására történtek lépések. Ezek jelentős sikerekhez is vezettek, pl. az Egyesült Államokban a dohányzók aránya 2004 és 2014 között 20,9\%-ról 16,8\%-ra csökkent, ezen belül a 18-24 évesek körében 24,4\%-ről 16,4\%-ra. Becslések szerint ennek hatása a 35 éves kohorsz várható élettartamára majdnem 1 év. ${ }^{8}$ Ugyanakkor a túlsúly válik ott (is) az egyik legsúlyosabb problémává. A 30 feletti BMI-indexszel ${ }^{9}$ rendelkezők aránya a 90-es évek elejétől 2014-ig 25\%-ról 40\%-ra nőtt. ${ }^{10}$ Gutterman számításai szerint ez több mint 1 évvel csökkenti a 35 éves korban várható élettartamot. Tehát a két hatás nagyjából kioltja egymást.

Hasonló következtetést vonhatunk le a 2. ábrából is. Úgy tűnik, hogy amint sikereket érünk el egy rossz szokás legyőzésében, egy másik lép a helyébe.

\section{2. ábra: Azok aránya, akik valaha is dohányoztak, vagy valaha is túlsúlyosak voltak}

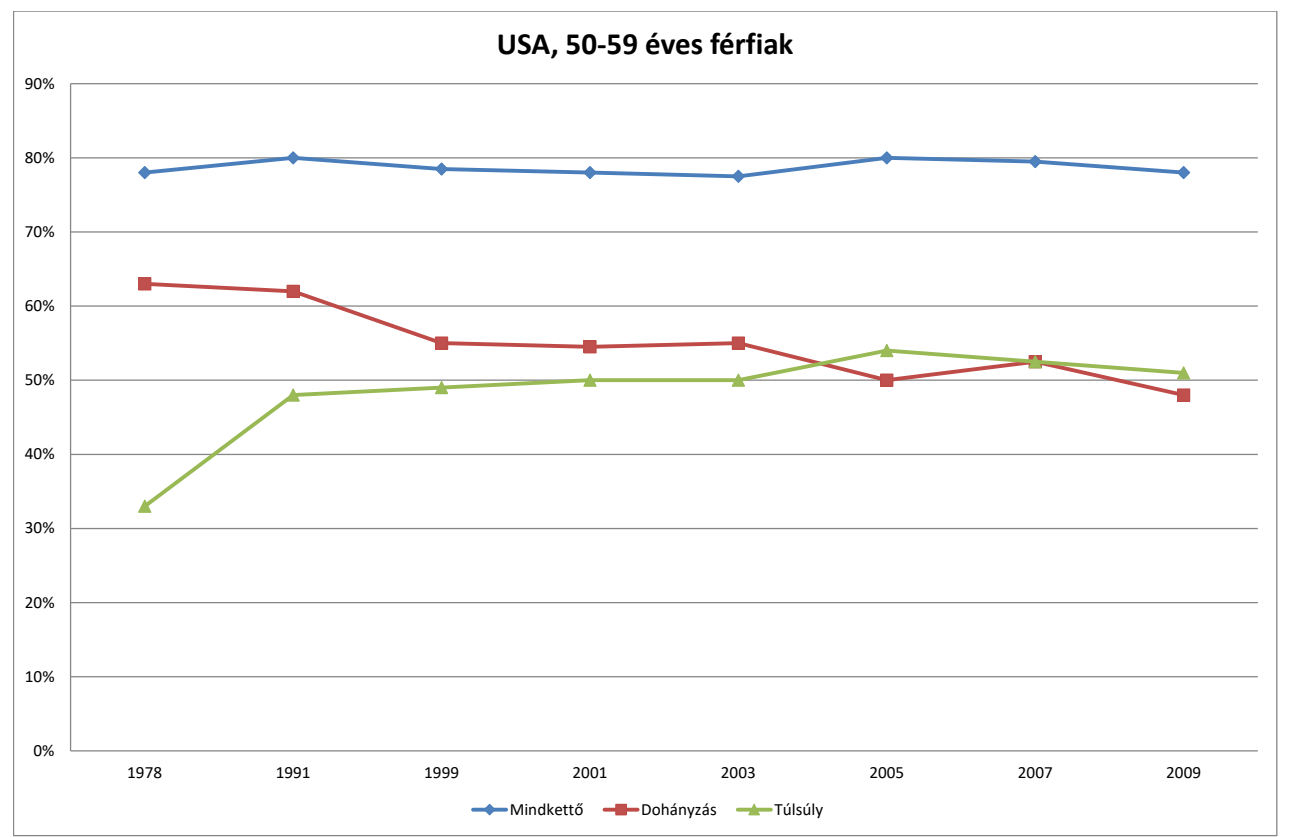

Forrás: Mehta-Myrskylä ${ }^{11}$

Természetesen a túlsúly és a dohányzás nem azonos módon hat a mortalitás alakulására, amint azt a 3. ábra szemléletesen összefoglalja. 
3. ábra: A dohányzás és a túlsúly hatása az egészségben és betegségben töltött évekre

\section{Férfiak}
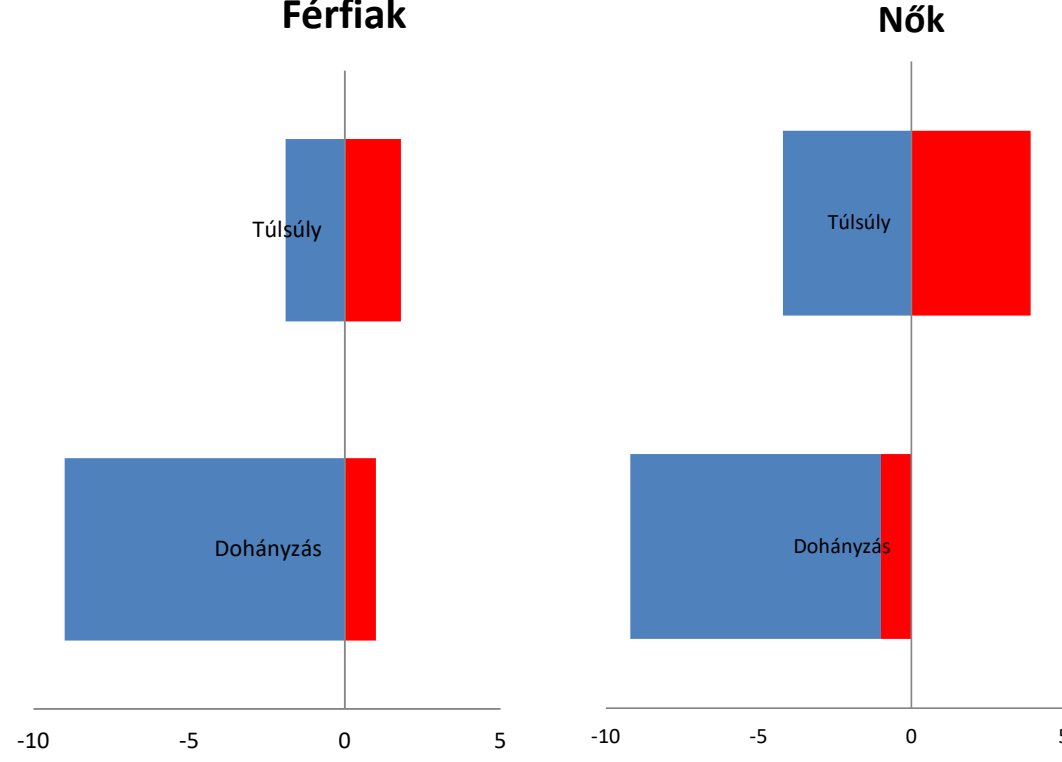

- Betegen töltött évek - Egészséges évek

Forrás: Mehta-Myrskylè

Míg a dohányzás jelentősen csökkenti a várható élettartamot, viszont alig növeli a nem-egészségesen töltött évek számát, addig a túlsúly kevésbé csökkenti az életkilátásokat, viszont jelentősen megnöveli a betegen töltött éveket. Ez komoly új kihívások elé állítja az egészségügyi ellátórendszereket. Emellett arra is rámutat, hogy nem elég a halandósági folyamatok elemzése, hanem arra is figyelemmel kell lennünk, hogy a megnövekedett életéveket egészségben vagy betegségben töltjük-e el. Ez a fajta elemzés azonban messze túlmutat e cikk keretein.

Más önpusztító jelenségek is megfigyelhetők. Az egyik ilyen az opioid tartalmú nyugtatószerek túlzott használata. Az Egyesült Államokban az ebből fakadó halandóság 1999 és 2016 között 0,3\%o-röl 1,3\%o-re nőtt. ${ }^{12}$

\section{Piketty ${ }^{13}$ nyomán}

A társadalmi egyenlőtlenségek halandóságot befolyásoló volta jó ideje ismert volt az aktuáriusok előtt, hiszen - a kockázatelbírálási tevékenység mellett - ez az oka annak, hogy a biztosítotti halandóság tendenciájában kisebb, mint a néphalandóság. Magyarországon
Marosi Judit több tanulmányban mutatta meg, hogy a nyugdíjasok körében nagyobb nyugdíjakhoz alacsonyabb halandóságok tartoznak (természetesen statisztikailag). ${ }^{14}$ Hasonlóképpen egy, az Egyesült Királyság adataira támaszkodó kutatás kimutatta, hogy az iskolai végzettség, illetve a társadalmi státusz komoly befolyásoló tényező a halandóságban. ${ }^{15} \mathrm{~A}$ kérdés témánk szempontjából természetesen az, hogy az egyenlőtlenségek sok kutató által kimutatott növekedése hogyan hat a halandóságra, illetve annak társadalmi szerkezetére?

Egy amerikai akadémiai ${ }^{16}$ kutatás azt mutatta meg, hogy a különböző jövedelmi csoportokban hogyan alakult az 50 éves korban várható élettartam változása az 1930ban, illetve 1960-ban született kohorszok esetében. Mint a 4. ábrán láthatjuk, a várható élettartam a legalsó társadalmi ötödben nemhogy nőtt volna, hanem inkább csökkent, a férfiak esetében növekedést csak a felső 60\%-nál látunk, a nők esetében pedig csak a legfelső 20\%-nál. Tehát a halandóság javulása (legalábbis az Egyesült Államokban) csak a magasabb társadalmi csoportok esetében figyelhető meg. Amennyiben kevés gazdagot és sok szegényt tartalmazó társadalom felé haladunk, ez óhatatlanul lassítja, sőt meg is állíthatja a halandóság javulását.

4. ábra: Várható élettartam 50 éves korban jövedelmi kvintilisenként, USA
Férfiak

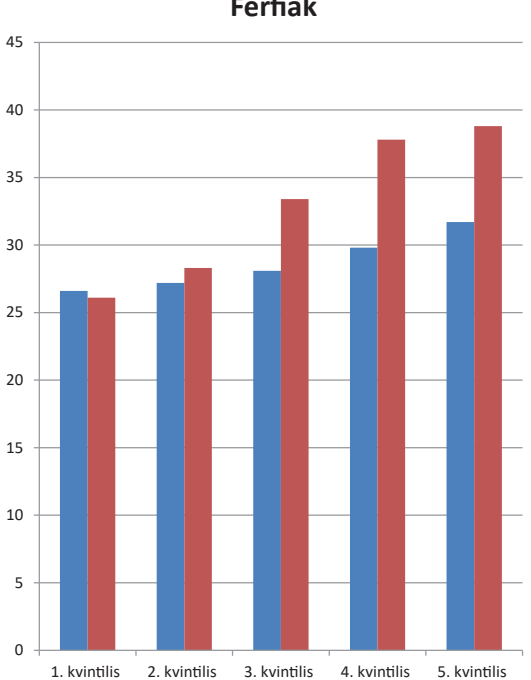

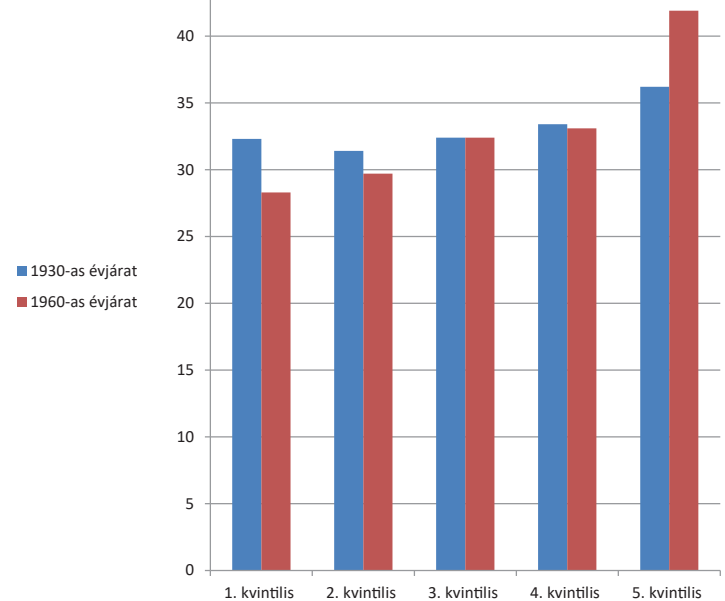

Forrás: The Growing Gap in Life Expectancy by Income 
Mindezt erősítheti, ha a jóléti állam már nem tudja finanszírozni a növekvő egészségügyi költségeket, és a magas szintű ellátás egy szűkülő réteg privilégiuma lesz. (5. ábra)

5. ábra: Egészségügyi kiadások növekedése és a várható élettartam változása - Anglia és Wales
A Nemzeti Egészségügyi Szolgálat

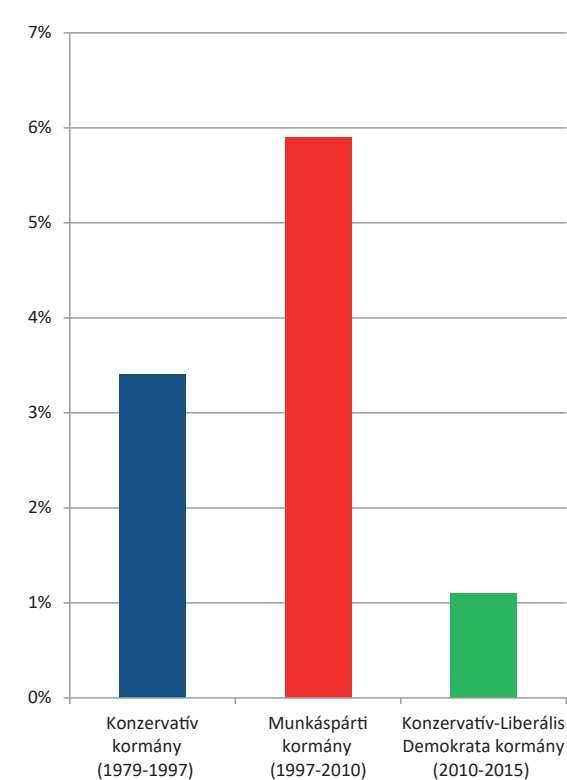

(NHS) éves kiadásnövekedése
65 éves korban várható élettartam éves növekedés -Anglia és Wales

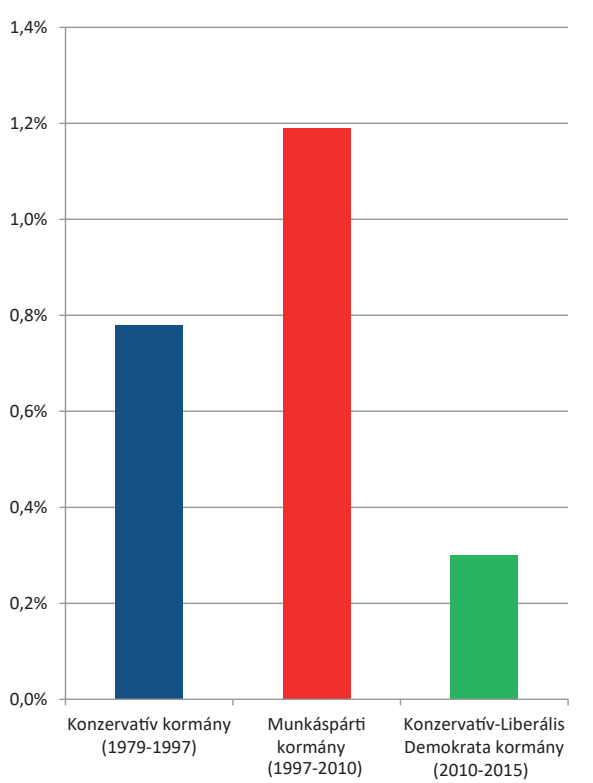

Forrás: Ridsdale, Brian (2017)

\section{Nem átmeneti jelenség}

Léteznek olyan adatok, amelyek mintha azt mutatnák, hogy nem átmeneti a jelenség, hanem a javulás forrásai szükültek be. Angol és walesi adatok alapján levonhatjuk azt a következtetést, hogy a halandóság javulása (legalábbis e két országrészben) elsősorban a kardiovaszkuláris halandóság javulása miatt következett be az időskori népesség esetében. Ennek további jelentős javulására már nem számíthatunk, ezért a javulás lassul, vagy megáll. Természetesen e nézet igazolásához sok országra kiterjedő részletes haláloki vizsgálatokra lenne szükség. ${ }^{17}$

\section{Következtetések}

A halandóság javulásának lassulása tényleges jelenség. Ugyanakkor túlságosan rövid ideje tart ahhoz, hogy megbízható állításokat tehessünk vele kapcsolatban. A lehetséges magyarázatok köre is rendkívül szerteágazó. A jelenség már Magyarországot is elérte, így fontos, hogy megfelelő hazai elemzések is szülessenek róla, illetve kövessük a nemzetközi irodalmat. Az életbiztosítók számára is fontos lehet, hogy előre becsüljük termékeink profitabilitását. Az azonban már most is biztos, hogy hagyományos modelljeinket, amelyek a múltbeli tendenciákat terjesztik ki a jövőre, mostanában csak nagy óvatossággal használhatjuk. 


\section{HIVATKOZÁSOK}

'United Nations, Department of Economic and Social Affairs, Population Division (2019). World Population Prospects 2019, Online Edition. https://population.un.org/wpp/ 2019.07.04.

2Ruandában a szuleteskor varható elettartam ebben az idöszakban a férfiaknál 20 évre csökkent.

${ }^{3}$ A Szovjetunióban 1985 májusában bevezetett alkoholizmusellenes intézkedéscsomag népi neve.

${ }^{4}$ Bennett et al.: The future of life expectancy and life expectancy inequalities

in England and Wales: Bayesian spatiotemporal forecasting, The Lancet. July 2015

${ }^{5}$ Ridsdale, Brian: Is mortality still improving? Elóadás az MVG 2017 .
${ }^{6}$ The Human Mortality Database https://mortality.org/ 2019.07.01.

'FuroMOMO. http://www.euromomo.eu/ 2019.07.20

${ }^{8} \mathrm{~S}$ Sam Gutterman: To what extent will human behavior affect mortality projections? Elöadás az MWG 2019. április 21-I ̈̈lésén, Budapest. ${ }^{9} \mathrm{BMI}$ index $=$ testsúly $(\mathrm{kg}) /$ testmagasság2 $(\mathrm{cm}) 2$

"Guttermann i.m. Disability Delayed. HealthAffairs 2017. augusztus

12Ridsdale, Brian: Recent development in longevity, internatonally. Webcast 2018. július 13 .

${ }^{13}$ Thomas Piketty francia közgazdász, az egyenlötlenségek talán legismertebb kutatója. Fő műve a Töke a 21. században.

"Legutóbb: Marosi J. - Molnár D. L. (2018): Öregségi nyugdijasok halandósága 2015-ben. Statisztikai Szemle, 96. évf. 1.szám, pp. 5-26. ${ }^{15}$ Andrew J. G. Cairns: IFoA International Research in Mortality. Előadás az MWG 2017. április 19-i ülésén, Budapesten.

${ }^{16}$ The Growing Gap in Life Expectancy by Income. The National Academy Press 2015. p. 52.

${ }^{17}$ Ridsdale, Brian: (2017)

United Nations, Department of Economic and Social Affairs, Population Division (2019). World Population Prospects 2019

I9United Nations, Department of Economic and Social Affairs, Population Division (2019). World Population Prospects 2019.
O Online Edition 17)

\section{IRODALOMJEGYZÉK}

Bennett et al.: The future of life expectancy and life expectancy inequalities in England and Wales: Bayesian spatiotempora forecasting, The Lancet, July 2015

Crist Andrew JG. április 19-i ülésén, Budapesten

https://WwW actuaries_org/CTTEES_TFM/Documents/Budapest_April2017/5_Cairns_Budapest2017B_final pdf Letöltésideje

The Growing Gap in Life Expectancy by Income, The National Academy Press 201

Grimaion

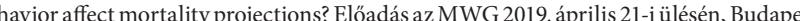

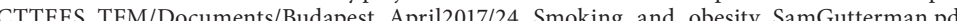
https://WwW.actuaries.org
Letotoltés ideje 2019.07.20

The Human Mortality Database https://mortality.org/ Letöltés ideje 2019.07.01.

Marosi J., Molnar D. L. (2018): Öregségi nyugdijasok halandósága 2015-ben. Statisztikai Szemle, 96. évf. 1. szám, pp. 5-26,

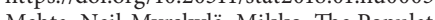

tealth Benefits Of A Healthy Lifestyle: Life Expectancy Increased And Onset O . 2017. augusztus

tttps://doi.org/10.1377/hlthaff.2016.1569

Mikko Myrskylä: Bad behaviors and disabled ageing. Elöadás ICA 2018. június 4-én

Ridsdale, Brian: Is mortality still improving? Elöadás az MVG 2017. április 19-i ülésén

Ridsale, Bhan: Decent developp

Edition, https://population un.org/wpp/ Letöltés ideje 2019.07.04

\section{MELLÉKLETEK}

1. melléklet:

Születéskor várható élettartam (férfiak)

\begin{tabular}{|c|c|c|c|c|c|c|c|c|c|c|c|c|c|c|c|}
\hline & \begin{tabular}{|l}
$1950-$ \\
1955
\end{tabular} & $\begin{array}{l}1955- \\
1960\end{array}$ & $\begin{array}{l}\begin{array}{l}1960- \\
1965\end{array} \\
\end{array}$ & $\begin{array}{l}1965- \\
1970\end{array}$ & $\begin{array}{l}1970- \\
1975\end{array}$ & $\begin{array}{l}1975 \\
1980\end{array}$ & & $\begin{array}{l}980- \\
985\end{array}$ & $\begin{array}{l}1985- \\
1990\end{array}$ & $\begin{array}{l}1990- \\
1995\end{array}$ & $\begin{array}{l}1995- \\
2000\end{array}$ & $\begin{array}{l}2000- \\
2005\end{array}$ & $\begin{array}{l}2005- \\
2010\end{array}$ & $\begin{array}{l}2010- \\
2015 \\
\end{array}$ & $\begin{array}{l}2015- \\
2020\end{array}$ \\
\hline $\begin{array}{l}\text { Afrika (Szaharától } \\
\text { délre) }\end{array}$ & 35,0 & 37,3 & 39,9 & 41,9 & 43, & & & 47,1 & 48,0 & 47,4 & 47,7 & 49,1 & 52,6 & 56,2 & 58,8 \\
\hline $\begin{array}{l}\text { Eszzak-Affika és } \\
\text { Nyugat-Ázsia }\end{array}$ & 41,0 & 44,3 & 47,4 & 50,5 & 53, & & & 58,6 & 61,8 & 63,6 & 65,5 & 67,3 & 68,8 & 70,1 & 71,3 \\
\hline Közzép- és Dél-Ázsia & 38,3 & 41,5 & 44,6 & 47,5 & 50, & & & 54,5 & 56,7 & 59,1 & 61,1 & 63,0 & 64,8 & 66,8 & 68,2 \\
\hline Azsia & 43,7 & 45,3 & 46, & 54,3 & 59, & & & 64,8 & 66,3 & 66,9 & 68,0 & 69,8 & 71,1 & 72,3 & 73, \\
\hline $\begin{array}{l}\text { Lamn-Amenk } \\
\text { karibi térség }\end{array}$ & 49,7 & 52,4 & 54, & 56,7 & 58 & & & 62,4 & 64,1 & 65,8 & 67,5 & 69,0 & 70,2 & 71,2 & 72,0 \\
\hline Austrália és Új-Zéland & 66,9 & 67,7 & 67, & 67,7 & 68, & & & 71,6 & 72,8 & 74,5 & 75,8 & 77,6 & 79,0 & 80,2 & 81,1 \\
\hline $\begin{array}{l}\text { Óceánia } \\
\text { Furóna e }\end{array}$ & 37,6 & 41,5 & 44,3 & 47,6 & 50, & & & 55,9 & 57,3 & 58,7 & 59,8 & 61,0 & 62,3 & 63,5 & 64,9 \\
\hline Amerika & 62,3 & 64,9 & 66, & 66,7 & 67, & & & 68,4 & 69,6 & 69,5 & 70,2 & 71,0 & 72,6 & 74,5 & 75,4 \\
\hline Kelet-Európa & 56,9 & 62,0 & 64,7 & 64,9 & 64 & & & 63,6 & 65,2 & 63,1 & 62,5 & 62,4 & 1 & 67,2 & 69,0 \\
\hline Észak- & 6,3 & 6 & 8,2 & 3,8 & 69 , & & & 70,8 &, 0 & 72,6 & 73,7 & 75,2 &, 6 & 3 & 18,9 \\
\hline De & 61,8 & 6. & 65, & 6 & 68, & & & 70,8 & 0 & 12,8 & 2 & 6 & & 78,5 & 79,5 \\
\hline Nyugat & 65,3 & 00,0 & 67, & $6 /, 9$ & 68, & & & 70,7 & 72,0 & 73,0 & 74,4 & 75,8 &, 3 & 78,4 & 79,2 \\
\hline Észzak- & & 66,7 & 66. & & 7,7, & & & 70,9 & 71,6 & 72,5 & 73,8 & 7,8 & 75,9 & 76,8 & 76,7 \\
\hline Vilag & 45,5 & 47,8 & 49. & 53,5 & 56, & & & 59,8 & 61,5 & 62,2 & 63,3 & 64,8 & 66,7 & 68,5 & 69 \\
\hline
\end{tabular}

Forrás: NSSZ $^{18}$

2. melléklet:

Születéskor várható élettartam (nők)

\begin{tabular}{|c|c|c|c|c|c|c|c|c|c|c|c|c|c|c|}
\hline & $\begin{array}{l}1950- \\
1955\end{array}$ & $\begin{array}{l}1955- \\
1960\end{array}$ & $\begin{array}{l}1960- \\
1965\end{array}$ & $\begin{array}{l}1965- \\
1970\end{array}$ & ${ }_{1975}^{1970-}$ & $\begin{array}{l}1975- \\
1980\end{array}$ & $\begin{array}{l}1980- \\
1985\end{array}$ & 1985- & $\begin{array}{l}1990- \\
1995\end{array}$ & $\begin{array}{l}1995- \\
2000\end{array}$ & $\begin{array}{l}2000- \\
2005\end{array}$ & $\begin{array}{l}2005- \\
2010\end{array}$ & $\begin{array}{l}2010- \\
2015\end{array}$ & $\begin{array}{l}2015- \\
2020\end{array}$ \\
\hline \begin{tabular}{|l|l|}
$\begin{array}{l}\text { Afrika (Szaharától } \\
\text { dérre) }\end{array}$ \\
\end{tabular} & 37,7 & 40, & 42,3 & 44,3 & 46,4 & 48,4 & 50,0 & 5 & 50,9 & 51,1 & 52,1 & 55,5 & 59,5 & 62,3 \\
\hline \begin{tabular}{|l} 
EEzzak-Artrik \\
Nyugat-Ázs
\end{tabular} & 44,2 & 47,7 & 50,7 & 53,8 & 56,7 & 60,1 & 63.7 & 66,5 & 68.5 & 70,3 & 71.8 & 73,5 & 74,7 & $75,7$. \\
\hline $\begin{array}{l}\text { Közzép-é } \\
\text { Keletés }\end{array}$ & 37,2 & 40, & 43,5 & 46,7 & 49,6 & 53,3 & 55,9 & 58,0 & 60,5 & 63,0 & 65,1 & 67,1 & 69,4 & 70,9 \\
\hline Azs & 47,3 & 49, & 49,9 & 58,8 & 63,2 & 66,1 & 68,7 & 70,4 & 71,7 & 73,0 & 74,3 & 75,9 & 77,6 & 79,0 \\
\hline karibi térsés & 53,2 & 56,1 & 58,9 & 61,3 & 63,8 & 66,1 & 68,3 & 70,3 & 72,2 & 74,0 & 75,6 & 76,8 & 77,7 & 78,5 \\
\hline & & & & & & & & & & & & & & \\
\hline $\begin{array}{l}\text { Óceánia } \\
\text { Európa és Észak- }\end{array}$ & 39,1 & 42,8 & 46,1 & $49, c$ & 52,9 & 55,9 & 58,8 & 60,4 & 61,7 & 62,9 & 63,9 & 65,3 & 66,5 & 67,8 \\
\hline Amerik & 67,6 & 70,6 & 72,5 & $73,$. & 74,4 & 75,4 & 76,2 & 77,0 & 77,5 & 77,9 & 6 & 79,7 & 80,9 & 81,6 \\
\hline Kele & & & & & & & & 1 & & & & & & 78,4 \\
\hline & & & & & & & & & & & & & & 3,1 \\
\hline & 65,7 & 68, & 70,7 & 7 & & & & & & & & & & 84,5 \\
\hline $\begin{array}{l}\text { Nyygata-Európa } \\
\text { Észak-Amerika }\end{array}$ & $\begin{array}{l}70,1 \\
71,8\end{array}$ & $\begin{array}{l}72,1 \\
73,1\end{array}$ & $\begin{array}{l}73,4 \\
73,7 \\
-10\end{array}$ & 4.3 & $\begin{array}{l}77,1 \\
75,5\end{array}$ & $\begin{array}{l}76,4 \\
77,2\end{array}$ & $\begin{array}{l}77,6 \\
78,1\end{array}$ & $\begin{array}{l}78,9 \\
78,6\end{array}$ &, 2 & $\begin{array}{l}81,0 \\
79,5\end{array}$ & ? & $\begin{array}{l}83,0 \\
80,9\end{array}$ & $\begin{array}{l}83,7 \\
81,6\end{array}$ & 81,6 \\
\hline ilág & 48,5 & 5 & 52,9 & 57,4 & 60,0 & 62,4 & 64,4 & 65,9 & 67,0 & 68,1 & \begin{tabular}{|l|l|} 
& 69,4 \\
\end{tabular} & 71,3 & 73,3 & 74,7 \\
\hline
\end{tabular}

Forrás: $E N S Z^{19}$ 